\title{
Founding of the International Society for Zinc Biology
}

\section{August 2008}

We are delighted to announce the founding of the International Society for Zinc Biology (ISZB). Zinc is well known to biologists for its roles as an essential cofactor for many enzymes active in digestion and metabolism, and in transcription factors active in the control of gene expression. Recently, it has become increasingly appreciated that zinc also plays critical roles in the nervous, reproductive and immune systems, as well as in embryonic development. Evidence is accumulating that zinc has important functions in regulating signal transduction cascades in the cell and may be involved in several diseases, including Alzheimer disease, diabetes, stroke, cancer, wound healing and macular degeneration of the eye. The Society is an international, nonprofit organization; one of our driving goals is to bring together scientists from a diversity of fields that have a common interest in the structural, biochemical, genetic and physiological aspects of zinc biology. Membership is open to individuals from any nation, including scientists, students, physicians, regulators, sponsors, and any other professionals interested in zinc biology. Further details and information on future meetings, current members, and how to join the Society can be found on our website: http://www.ISZB.org.

For further information contact:

Professor Glen K. Andrews

President of the Society

gandrews@kumc.edu

or contact us via the E-mail address of the society sfzb@gmail.com 